\title{
The alkaline pectate lyase PEL168 of Bacillus subtilis heterologously expressed in Pichia pastoris is more stable and efficient for degumming ramie fiber
}

\author{
Chengjie Zhang ${ }^{1}$, Jia Yao', Cheng Zhou², Liangwei Mao', Guimin Zhang ${ }^{1 *}$ and Yanhe Ma
}

\begin{abstract}
Background: The conventional degumming process of ramie with alkaline treatment at high temperature causes severe environmental pollution. Pectate lyases can be used to remove pectin from ramie in a degumming process with reduced environmental pollution and energy consumption. Pectate lyase PEL168 from Bacillus subtilis has been previously characterized and the protein structure was resolved. However, Bacillus is not a suitable host for pectate lyases during the degumming process since most Bacillus produce cellulases endogenously with a detrimental effect to the fiber. Pichia pastoris, which does not express endogenous cellulases and has high secretion capability, will be an ideal host for the expression. No previous work was reported concerning the heterologous expression of pectate lyase PEL168 in P. pastoris with an aim for industrial application in ramie bio-degumming.

Results: The gene pel168 was expressed in P. pastoris in this study. The recombinant protein PEL168 in P. pastoris (PEL168P) showed two bands of $48.6 \mathrm{kDa}$ and $51.4 \mathrm{kDa}$ on SDS-PAGE whereas the enzyme expressed in E. coli (PEL168E) was the same as predicted with a band of $46 \mathrm{kDa}$. Deglycosylation digestion suggested that PEL168P was glycosylated. The optimum reaction temperature of the two PEL168s was $50^{\circ} \mathrm{C}$, and the optimum $\mathrm{pH} 9.5$. After preincubation at $60^{\circ} \mathrm{C}$ for 20 min, PEL168E completely lost its activity, whereas PEL168P kept 26\% of the residual activity. PEL168P had a specific activity of $1320 \mathrm{U} / \mathrm{mg}$ with a $K_{m}$ of $0.09 \mathrm{mg} / \mathrm{ml}$ and a $V_{\max }$ of $18.13 \mu \mathrm{mol} / \mathrm{min}$. $\mathrm{K}^{+}$, $\mathrm{Li}^{+}, \mathrm{Ni}^{2+}$ and $\mathrm{Sr}^{2+}$ showed little or no inhibitory effect on PEL168P activity, and $\mathrm{Ca}^{2+}$ enhanced enzyme activity by 38\%. PEL168P can remove the pectin from ramie effectively in a degumming process. A 1.5 fold increase of PEL168 enzyme expression in P. pastoris was achieved by further codon optimization.
\end{abstract}

Conclusions: Pectate lyase PEL168 with an available protein structure can be heterologously expressed in P. pastoris. The characterized recombinant PEL168P can be used to remove pectin from ramie efficiently and the expression level of PEL168 in P. pastoris was increased markedly by codon optimization. Therefore, PEL168 is an ideal candidate for further optimization and engineering for bio-degumming.

Keywords: Bacillus subtilis, Pectate lyase, Pichia pastoris, Glycosylation, Degumming, Codon optimization

\section{Background}

Ramie (Boehmeria nivea) produces one of the strongest and longest plant fibers that are used for clothing fabrics, industrial packaging, twines, cordages, canvas, car outfits, etc. However, despite excellent properties and diverse applications, ramie has failed to become a major textile

\footnotetext{
* Correspondence: zhangguimin6@hotmail.com

'College of Life Sciences, Hubei University, Wuhan 430062, China

Full list of author information is available at the end of the article
}

crop mainly due to difficulties in processing the fiber. Natural ramie fibers contain gum-like material that has to be removed before most application. The conventional degumming process is performed with alkaline treatment at high temperature, which causes fiber damage while increasing energy consumption and severe environmental pollution.

Pectate lyases are a group of enzymes that catalyze hydrolysis of $\alpha-1,4$-glycosidic bond of pectin polymer. In

\section{Biomed Central}

(c) 2013 Zhang et al.; licensee BioMed Central Ltd. This is an Open Access article distributed under the terms of the Creative Commons Attribution License (http://creativecommons.org/licenses/by/2.0), which permits unrestricted use, distribution, and reproduction in any medium, provided the original work is properly cited. 
industry, these enzymes, combined with other enzymes, can be used to efficiently remove ramie gum under mild conditions so that the use of harsh chemicals can be significantly reduced [1]. Hence, enzymatic degumming can serve as a good alternative to conventional degumming method, with a decreased environmental pollution and energy consumption as well as an improved yield and quality of degummed ramie [2]. For enzymatic degumming of fibers at an industrial scale, it is important to produce cost-efficient, effective and cellulase-free pectate lyase.

Pectate lyases have been isolated from various microbial sources such as yeasts, actinomycetes, bacteria and fungi. In application, alkaline pectate lyase is preferred for efficiently removing pectin from ramie, since pectin is more soluble in alkaline solution. Alkaline pectate lyases are produced predominantly by the genus Bacillus [3-5]. However, Bacillus is not a suitable host for pectate lyases during the degumming process since most Bacillus produce cellulases endogenously with a detrimental effect to the fiber. In contrast, $P$. pastoris has no endogenous cellulases expression and secrete heterologous proteins, serving as a good host for pectate lyase expression and application. In addition, proteins expressed by $P$. pastoris were sometimes $\mathrm{N}$-glycosylated and had improved thermo-stability [6,7], which made P. pastoris more suitable for industrial application [8].

The genome of Bacillus subtilis subsp. subtilis str. 168 has been sequenced previously [9], and the pectate lyase gene pel168 of this strain has been identified and expressed in Escherichia coli BL21 (DE3) for analysis of protein structure [10]. Five putative N-glycosylation sites on PEL168 can be deduced from the sequence. However, No previous work was reported concerning the heterologous expression in $P$. pastoris and the ramie degumming experiments by PEL168.

With a long-term goal to produce low-cost pectate lyase in industry application, structure based enzyme engineering is a major technical pathway to obtain optimized enzymes for industrial degumming. In the mean time, finding an ideal host for heterologous expression of the optimized enzyme is also essential for the large scale application. Therefore, we tested the expression of the alkaline pectate lyase gene pel168 in P. pastoris and investigated the effectiveness of the recombinant enzyme PEL168 on degumming in this research. The data showed that the gene pel168 can be expressed in $P$. pastoris and recombinant PEL168 can be used to remove pectin from ramie efficiently in degumming process. In order to improve the expression level, the pel168 was further optimized according to the codon bias of $P$. pastoris to obtain 1.52 fold increase in extracellular activity. This is the first report that pectate lyase PEL168 can be used to remove pectin from ramie efficiently and that codon optimization was successfully used to increase the expression of pectate lyase in $P$. pastoris.

\section{Results}

\section{Sequence analysis of pectate lyase PEL168}

The nucleotide sequence of pectate lyase gene pel168 from B. subtilis 168 was obtained from GenBank (accession number: AL009126). The estimated molecular mass of PEL168 was $46 \mathrm{kDa}$ with a 21-residue signal peptide [11]. Five putative N-glycosylation sites (Asn-X-Thr/Ser) were found: three of them were near to the $\mathrm{N}$ terminus (N-48, N-127, N-184), and the other two were near the C terminus (N-345, N-351).

\section{Expression and deglycosylation of recombinant PEL168 expressed in P. pastoris}

The gene pel168 of $B$. subtilis 168 was cloned into the $E$. coli expression vector pET28a and $P$. pastoris expression vector pHBM905A, respectively. To distinguish PEL168 expressed in E. coli and P. pastoris, the two enzymes were named PEL168E and PEL168P, respectively. The enzyme was purified and the purity was quantified by SDS-PAGE. Purified PEL168E showed one band with a molecular mass of $46 \mathrm{kDa}$ (Figure 1), as predicted. However, PEL168P had two bands with molecular masses of 48.6 and $51.4 \mathrm{kDa}$, respectively (Figure 1), both larger than predicted. After a deglycosylation step by endoglycosidase $\mathrm{H}$, only one band showed on SDS-PAGE, with the same size as the one expressed in E. coli, which suggested that the recombinant PEL168P had different degrees of glycosylation. Comparison of the molecular masses of the enzymes before and after deglycosylation showed that the percentages of glycosylation of the two fragments were 5\% and $12 \%$, respectively.






\section{Effect of cultivation temperature on PEL168P expression in $P$. pastoris}

Transformant $P$. pastoris GS115-pel168 was cultured in BMMY liquid medium. The enzyme activity in culture supernatants was assayed daily for 5 days. As shown in Figure 2A, the time of optimal secretion of PEL168P was 4 days at two incubation temperatures. Maximum values of pectate lyase activity in culture supernatants were 102.56 and $83.12 \mathrm{U} / \mathrm{ml}$ at $25^{\circ} \mathrm{C}$ and $30^{\circ} \mathrm{C}(34.5$ and 27.07 $\mathrm{U} / \mathrm{ml}$ with $\mathrm{A}_{235}$ method), respectively. The culture kept at $25^{\circ} \mathrm{C}$ provided about 1.2 -fold more activity than that kept at $30^{\circ} \mathrm{C}$.

\section{Characterization of the pectate lyase PEL168}

The activities of the recombinant PEL168s were measured at different temperatures (Figure 2B). The optimum reaction temperature of the two PEL168s (PEL168E and PEL168P) was both $50^{\circ} \mathrm{C}$, and the two enzymes both showed more than $50 \%$ activity from 35 to $55^{\circ} \mathrm{C}$. At $50^{\circ} \mathrm{C}$, the optimum $\mathrm{pH}$ for the two PEL168s was 9.5, and both enzymes had more than $60 \%$ activity from $\mathrm{pH} 9$ to 10 (Figure 2C). Therefore, PEL168 appears to be an alkalinestable enzyme. The thermo-stability of these two pectate lyases was also investigated. The enzymes were preincubated without the substrate at 40,50 and $60^{\circ} \mathrm{C}$, respectively. For designated time periods, the two kinds of enzymes retained more than $85 \%$ of their initial activity at $40^{\circ} \mathrm{C}$ for $30 \mathrm{~min}$. However, at $60^{\circ} \mathrm{C}$, PEL168E completely lost its activity after 20 min pre-incubation, whereas PEL168P kept $26 \%$ of its initial activity with the same treatment (Figure 2D).

PEL168P had better thermo-stability and was more suitable for industrial application than PEL168E. Thus, we characterized PEL168P in detail. Under the optimum conditions as described above, the enzyme had a specific activity of $1320 \mathrm{U} / \mathrm{mg}$ (452 U/mg with $A_{235}$ method)
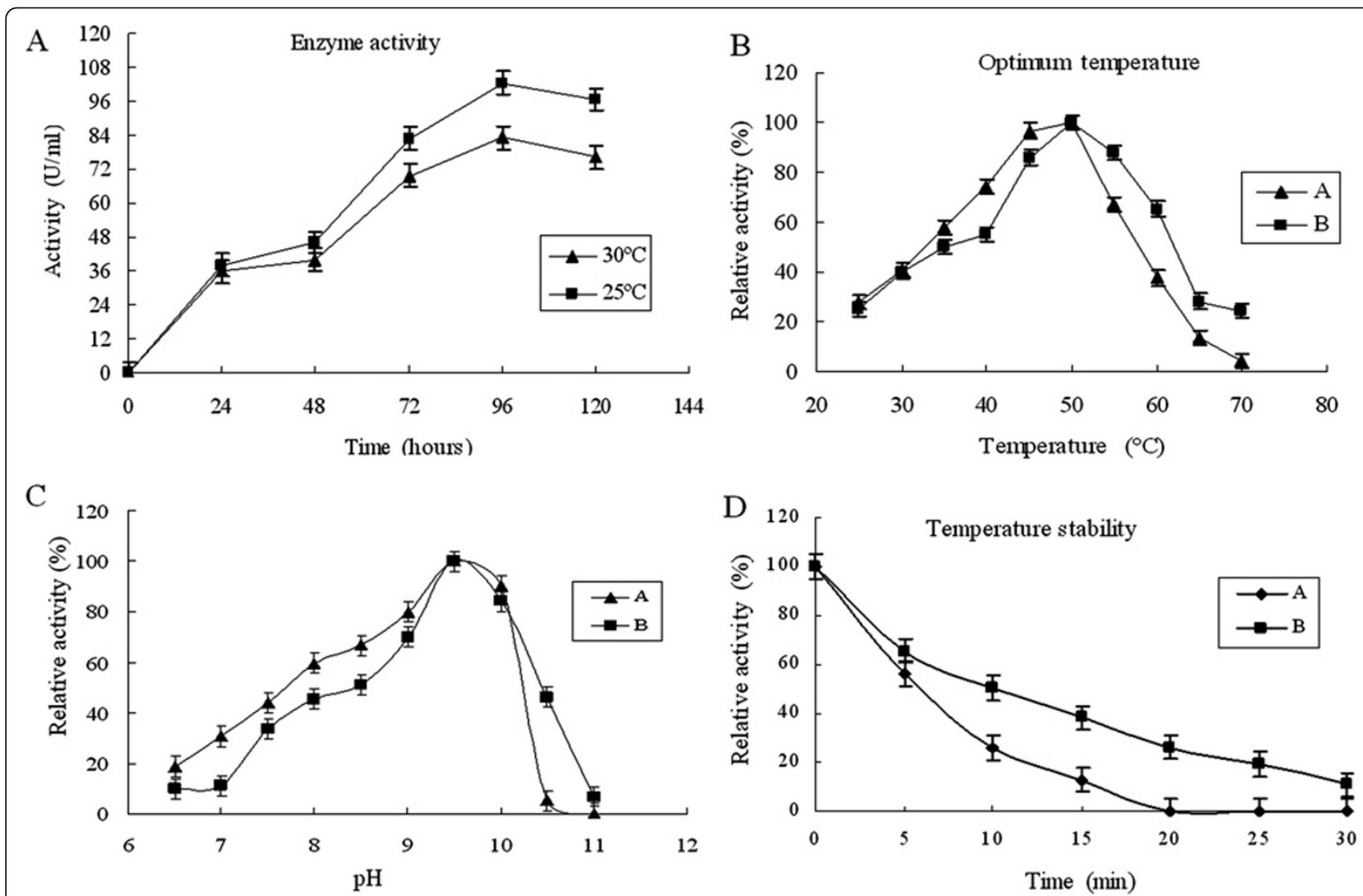

Figure 2 A, Effect of culture age and cultivation temperature on pectate lyase activity in the culture medium of $P$. pastoris. Pectate lyase activity at $25^{\circ} \mathrm{C}(\boldsymbol{\square})$. Pectate lyase activity at $30^{\circ} \mathrm{C}(\boldsymbol{\Delta})$. B, Effect of temperature on pectate lyase activity. Pectate lyase expressed in $P$. pastoris and E. coli was added to $50 \mathrm{mM}$ Gly-NaOH buffer (pH 9.4) and incubated at different temperatures for 10 min. Maximum activity was set to 100\%. A: recombinant PEL168E; and B: PEL168P. C, Effect of pH on pectate lyase activity. PEL168P and PEL $168 \mathrm{E}$ were respectively incubated for 10 min at $50^{\circ} \mathrm{C}$ at the indicated $\mathrm{pH}$ values in $50 \mathrm{mM}$ different buffer $\left[\mathrm{Na}_{2} \mathrm{HPO}_{4}\right.$-citric acid ( $\mathrm{pH}$ 4.0-6.0), sodium phosphate (pH 6.0-7.5), Tris- $\mathrm{HCl}$ (pH 7.5-8.8) and glycine- $\mathrm{NaOH}(8.8-10.6)]$. Maximum activity was set to 100\%. A, recombinant PEL168E; and B, PEL168P. D, Temperature stability of the purified pectate Iyase. PEL168P and PEL168E were respectively incubated in the absence of substrate for 30 min at $60^{\circ} \mathrm{C}$, and residual activity was measured as described in the methods section. The start-time enzyme activity was set to 100\%. A: recombinant PEL168P; and B: PEL168E. 
with a $K_{m}$ of $0.09 \mathrm{mg} / \mathrm{ml}$ and a $V_{\text {max }}$ of $18.13 \mu \mathrm{mol} / \mathrm{min}$. Table 1 showed the effects of various metal ions and chemicals on the enzyme activity of PEL168P. $\mathrm{K}^{+}, \mathrm{Li}^{+}$, $\mathrm{Ni}^{2+}$ and $\mathrm{Sr}^{2+}$ showed little or no inhibition effect on the enzyme activity. $\mathrm{Mn}^{2+}, \mathrm{Hg}^{2+}$ and $\mathrm{Cu}^{2+}$ inhibited the most enzyme activity. $\mathrm{Zn}^{2+}, \mathrm{Fe}^{3+}, \mathrm{Mg}^{2+}$ and $\mathrm{Co}^{2+}$ reduced the enzyme activity by $35-55 \%$. However, the enzyme activity was enhanced by $38 \%$ with $\mathrm{Ca}^{2+}$ addition. For the chemicals assayed, the purified enzyme completely lost its activity with SDS or EDTA. Tween-80, methanol, ethanol, isopropyl alcohol and glycerol showed slight or no inhibition effect on the enzyme activity, and DMSO showed $25 \%$ activation.

\section{Codon optimization of pel168}

In order to further increase the expression levels of pel168 in $P$. pastoris, the sequence of pel168 was optimized according to the codon bias of $P$. pastoris. Two hundred and ninety four nucleotides were substituted in the optimized sequence of pel168s. The $\mathrm{G}+\mathrm{C}$ content of the original gene is $46.5 \%$, as compared to $39.25 \%$ after codon optimization. The gene sequences before and after codon optimization were provided as Additional file 1. The expression analysis showed that transformants contained a single copy chromosomal integration of optimized pel168

Table 1 Effects of metal ions and chemicals on the activity of the pectate lyase

\begin{tabular}{|c|c|c|}
\hline Metal ions or chemicals & Concentration & Relative activity(\%) \\
\hline No addition & $0 \mathrm{mM}$ & 100.0 \\
\hline $\mathrm{K}^{+}(\mathrm{KCl})$ & $5 \mathrm{mM}$ & $102.8 \pm 2.325$ \\
\hline $\mathrm{Zn}^{2+}\left(\mathrm{ZnSO}_{4}\right)$ & $5 \mathrm{mM}$ & $34.5 \pm 3.657$ \\
\hline $\mathrm{Fe}^{3+}\left(\mathrm{FeCl}_{3}\right)$ & $5 \mathrm{mM}$ & $58.7 \pm 0.562$ \\
\hline $\mathrm{Mg}^{2+}\left(\mathrm{MgCl}_{2}\right)$ & $5 \mathrm{mM}$ & $35.5 \pm 1.246$ \\
\hline $\mathrm{Mn}^{2+}\left(\mathrm{MnCl}_{2}\right)$ & $5 \mathrm{mM}$ & $8.5 \pm 1.21$ \\
\hline $\mathrm{Co}^{2+}\left(\mathrm{CoCl}_{2}\right)$ & $5 \mathrm{mM}$ & $47.0 \pm 4.341$ \\
\hline $\mathrm{Hg}^{2+}\left(\mathrm{HgCl}_{2}\right)$ & $5 \mathrm{mM}$ & 0 \\
\hline $\mathrm{Cu}^{2+}\left(\mathrm{CuSO}_{4}\right)$ & $5 \mathrm{mM}$ & $6.6 \pm 1.564$ \\
\hline $\mathrm{Ca}^{2+}\left(\mathrm{CaCl}_{2}\right)$ & $5 \mathrm{mM}$ & $138.3 \pm 3.564$ \\
\hline $\mathrm{Ni}^{2+}\left(\mathrm{NiSO}_{4}\right)$ & $5 \mathrm{mM}$ & $81.8 \pm 0.957$ \\
\hline $\mathrm{Li}^{+}(\mathrm{LiCl})$ & $5 \mathrm{mM}$ & $103.3 \pm 2.451$ \\
\hline $\mathrm{Sr}^{2+}\left(\mathrm{SrCl}_{2}\right)$ & $5 \mathrm{mM}$ & $104.1 \pm 1.367$ \\
\hline EDTA & $5 \mathrm{mM}$ & 0 \\
\hline SDS & $0.5 \%$ & 0 \\
\hline Tween-80 & $0.5 \%$ & $100.7 \pm 3.124$ \\
\hline DMSO & $0.5 \%$ & $124.8 \pm 4.658$ \\
\hline methanol & $0.5 \%$ & $98.3 \pm 2.324$ \\
\hline ethanol & $0.5 \%$ & $103.4 \pm 1.246$ \\
\hline isopropyl & $0.5 \%$ & $99.6 \pm 2.154$ \\
\hline alcohol & $0.5 \%$ & $101.5 \pm 1.245$ \\
\hline
\end{tabular}

gene. And the transformant expressed 1.52 fold enzyme activity compared to the original pel168-containing strain under the same conditions, with enzyme activities in the supernatant of $166.74 \mathrm{U} / \mathrm{ml}$ and $109.7 \mathrm{U} / \mathrm{ml}$ (54.31 U/ml and $35.94 \mathrm{U} / \mathrm{ml}$ with $\mathrm{A}_{235}$ method), respectively.

\section{Effects of degumming by PEL168 expressed in P. pastoris}

The degumming effects are shown in Figure 3. The ramie textile treated by PEL168P became softer, smoother and whiter, compared with that treated only with $0.05 \mathrm{M}$ Gly-NaOH buffer. Dry weight measurement showed that enzyme-treated textile lost $15 \%$ weight. Residual content of gum was measured as $2 \%$ by alkaline treatment at high temperature. The textiles were also observed using a scanning electron microscope, and the enzyme-treated sample showed a smoother surface, suggesting that the gum-like material was mainly removed by pectate lyase PEL168P (Figure 4).

\section{Discussion}

Gum-like materials from natural ramie fibers are soluble at high temperature and alkaline conditions, so chemical degumming is usually performed with alkaline treatment at high temperature, which causes serious environmental pollution. Enzymatic degumming serves as a good alternative to reduce pollution and cause less fiber damage. Therefore, developing a cost-efficient bio-degumming process of ramie by alkaline pectate lyase or bio-chemical degumming methods represents a major future trend of degumming industry. The low-cost of alkaline pectate lyase will be a key issue for accelerating bio-degumming application in the ramie treatment process. So it is important to get the costefficient and thermo-stable petate lyase with an improved expression level in an ideal host. $P$. pastoris is a preferred host for heterologous protein production with fast growing and facilitated gene manipulation. Moreover, it can also secrete heterologous protein efficiently. Thus, there is no need to break the cell and the enzyme secreted is easy to purify, which makes $P$. pastoris a more suitable host for industrial application [8]. Specifically, $P$. pastoris is an attractive host for pectate lyase expression because it does not produce endogenous cellulases that weaken the fiber of ramie. In this study, the pectate lyase gene pel168 of Bacillus subtilis 168 was first successfully expressed in $P$. pastoris and the expression level was further increased by gene codon optimization.

The results in our study also indicated that the pectate lyase heterologously expressed in $P$. pastoris has different extents of glycosylation. It was reported that enzyme glycosylation in $P$. pastoris leads to better thermo-stability $[6,7,12]$. Although in the standard deglycosylation process, the pectate lyase must be denatured by boiling before being treated with endoglycosidase $\mathrm{H}$, which makes it impossible to compare catalytic performance of the 


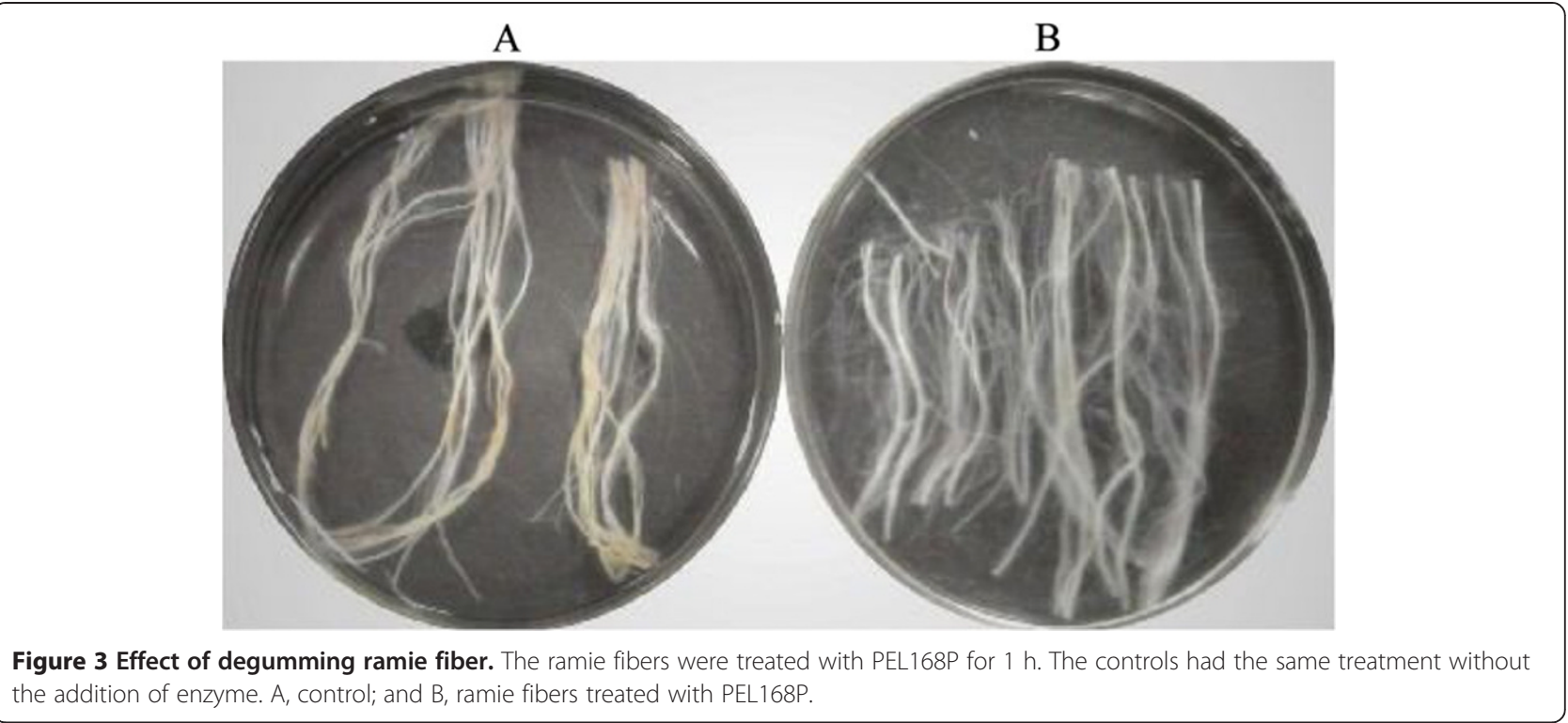

enzyme before and after deglycosylation. We described the influence of $\mathrm{N}$-glycosylation on PEL168 by comparing the properties of the N-glycosylated with the nonglycosylated PEL168E from $E$. coli. The result showed that N-glycosylation did improve PEL168 thermo-stability. Thus, PEL168P was more stable in application and more suitable for degumming.
There are also some reports about the expression and characterization of alkaline pectate lyase. Yuan et al. cloned alkaline pectate lyase gene from Xanthomonas campestris [13] and Streptomyces sp. S27 [14], and expressed in E. coli, respectively. The optimum temperatures of the recombinant pectate lyases from $X$. campestris and Streptomyces sp. S27 are $30^{\circ} \mathrm{C}$ and $60^{\circ} \mathrm{C}$, while the optimum pH are 9 and
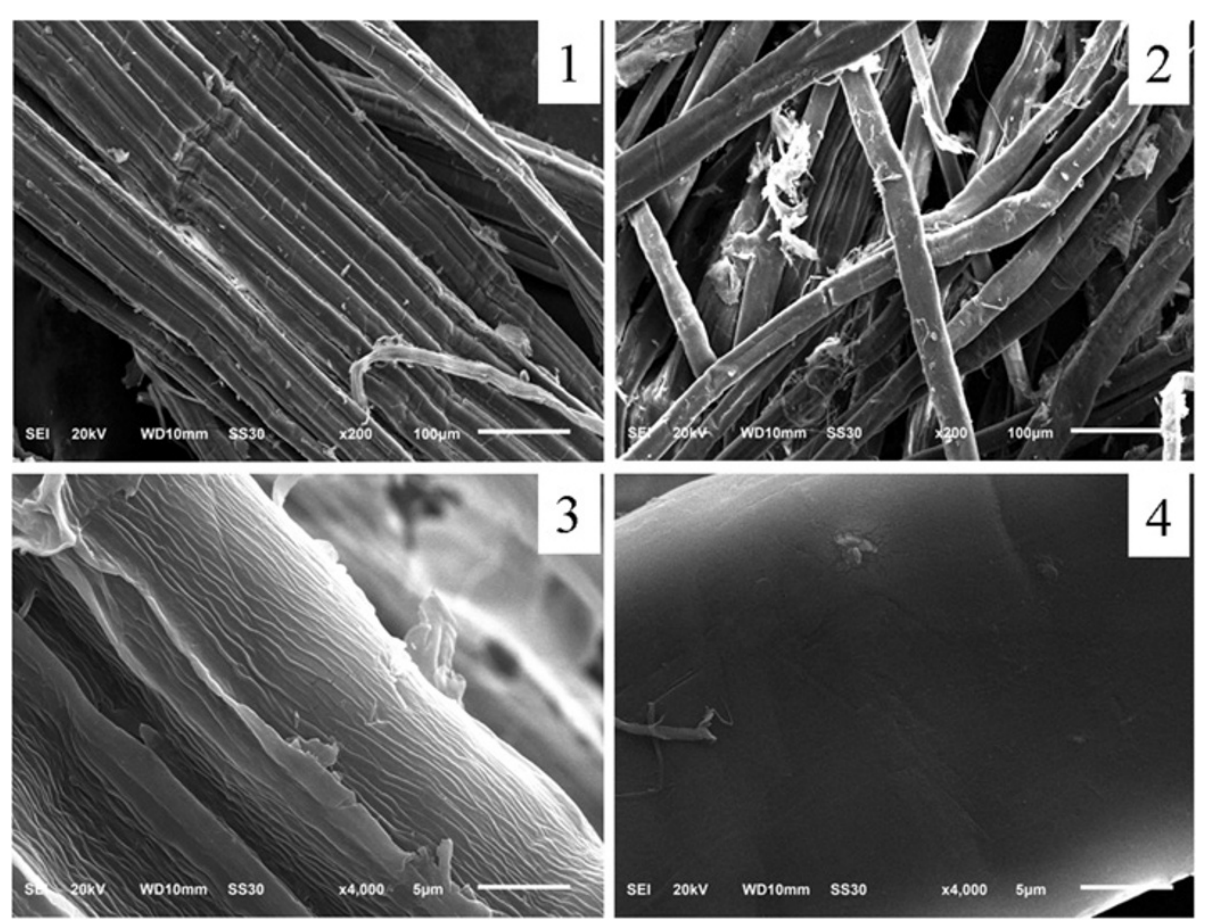

Figure 4 Scanning electron microscope of degumming ramie fiber. 1 (200x) and 3 (4000x), control; 2 (200x) and 4 (4000x), ramie fibers treated with PEL168P. 
10, respectively. A later effort by Solbak et al. leads to a candidate enzyme with an improved optimum temperature from $50^{\circ} \mathrm{C}$ to $70^{\circ} \mathrm{C}$ for the purpose of bioscouring [15]. Li et al. cloned an alkaline pectate gene from Bacillus sp. N16-5 and expressed it in E. coli. The optimum temperature and $\mathrm{pH}$ of the recombinant enzyme were $50^{\circ} \mathrm{C}$ and 11.5 [5]. Our initial trial to express alkaline pectate gene N16-5 in $P$. pastoris fails to get a high yield. We then turn our focus to the expression another alkaline pectate lyase which was originally isolated from $B$. subtilis 168 in P. pastoris. The recombinant PEL168P obtained in our current study displayed high efficiency at $\mathrm{pH} 9.5$ and $50^{\circ} \mathrm{C}$, with a specific activity $(1320 \mathrm{U} / \mathrm{mg})$ for removing the ramie pectin effectively in degumming process. This will provide a good starting point for further optimization of its thermo-stability and specific activity through protein engineering and strain engineering methods.

The codon optimization technique has been widely used to increase the expression levels of foreign proteins in $P$. pastoris $[16,17]$, but not always successfully, and there is no related report about pectate lyases yet. So we tried the strategy described above in this study so as to increase the expression level. Expression and fermentation analysis showed optimized pel168s expressed 1.52 fold enzyme activity compared to the original pel168. This is the first report of codon optimization successfully increasing the expression of pectate lyase in $P$. pastoris.

The cultivation temperature is also an important factor for optimal production of heterologous proteins. Previous investigations have shown that lower cultivation temperature might improve the production of heterologous protein in P. pastoris, such as laccase [6] and xylanase [7]. This was also observed in our study. Culture at $25^{\circ} \mathrm{C}$ provided about 1.2 -fold more activity than at $30^{\circ} \mathrm{C}$. It has previously been shown that a lower cultivation temperature improves the production of heterologous protein in $E$. coli [18], which can be attributed to aggregation problems at higher temperatures.

In the degumming experiment, our result also showed that PEL168P can remove gum efficiently from ramie with a reduced process time. In the previous reports, the biodegumming were usually performed by two ways. First, degumming was performed by isolated strains with high pectate lyase activity $[1,2,19]$. The degumming strains were inoculated on ramie fiber and incubated for a certain time, some degumming enzymes were produced with the growth of degumming strain so that the gum in the ramie fiber can be removed. For example, after $24 \mathrm{~h}$ of incubation with the isolated pectinolytic strain B. pumilus DKS1, the weight loss of the ramie fiber was found to be $25 \%$ under small scale [19]. This method requires longer time to perform degumming process because of the growth of degumming strains. Second, degumming was performed by enzymes from fermentation supernatant of isolated strains
$[20,21]$, which mainly includes pectate lyase and other polysaccharide-degrading enzymes. Culture supernatant of Amycolata sp. containing cellualse, xylanase and pectate lyase, reduced the gum content of ramie fibers by $30 \%$ within $15 \mathrm{~h}$ [20]. Brühlmann et al. [21] studied pectinolytic enzymes from actinomycetes for the degumming of ramie bast fibers. The gum content of the fibers decreased from $24 \%$ to $18 \%$ after $15 \mathrm{~h}$ treatment with crude enzyme preparations from a selection of actinomycetes at room temperature. This method also requires $15 \mathrm{~h}$ treatment since the activity of degumming enzyme isolated from wild strain is relatively low. From our data of SEM, the surface of the PEL168P-treated ramie looks smoother, which suggests that unique pectate lyase could also provide better degumming effects (Figure 4). As Compared to previous bio-degumming methods, the enzymatic degumming by PEL168P is more efficient and stable, with a minimal detrimental effect for fiber. Thus, PEL168P is a potential candidate to be used in bio-degumming process.

The protein structure information of pectate lyase PEL168 of Bacillus subtilis 168 is available now [10], which makes the enzyme rational design possible. Thus, PEL168P is a potential candidate for further improving the specific activity and reducing the cost so that it can be used in bio-degumming industry.

\section{Conclusions}

In general, the alkaline pectate lyase gene pel168 can be expressed in $P$. pastoris as a functional enzyme, and PEL168 can efficiently remove gum from ramie during the degumming process. In order to improve the expression level, the pel168 was further optimized according to the codon bias of $P$. pastoris and resulted in 1.52 fold increase in extracellular activity. This is the first report that glycosylation of pectate lyase can improve thermo-stability and the expression of pectate lyase in $P$. pastoris is increased by codon optimization.

\section{Methods}

\section{Strains}

B. subtilis subsp. subtilis str. 168 was gifted by Prof. Li Yongquan from Zhejiang University, China. E. coli XL-Gold, BL21 (DE3) and P. pastoris GS115 were purchased from Invitrogen.

\section{Gene cloning and sequence analysis}

The nucleotide sequence of pectate lyase gene pel168 from B. subtilis 168 was obtained from GenBank (accession number: AL009126). Signal peptide was analyzed by Signal P 3.0 Server (http://www.cbs.dtu.dk/services/ SignalP). N-glycosylation sites (Asn-X-Thr/Ser) were found by the NetNGlyC 1.0 Server (http://www.cbs.dtu.dk/ services/NetNGlyc). The codon optimized gene (pel168s) was designed by DNAworks (http://helixweb.nih.gov/ 
dnaworks/) and synthetized by Genscript, Nanjing, China. The sequence was also deposited in Genbank with accession number JQ655773.

\section{Construction of expression plasmid}

The gene pel168 of B. subtilis 168 was amplified by PCR. Primers P1, P2 and G1, G2 (Table 2) were designed for expression of pel168 in E. coli and P. pastoris, respectively. The PCR products based on primers $\mathrm{P}_{1}$ and $\mathrm{P}_{2}$ were digested with BamHI and NotI and then cloned into the $E$. coli expression vector pET28a, which was digested by the same restriction enzymes. The resultant plasmid was named pET28a-pel168. The PCR products based on primers $G_{1}$ and $G_{2}$ were digested with $T_{4}$ DNA polymerase supplemented with dTTP for $20 \mathrm{~min}$ at $12^{\circ} \mathrm{C}$ to obtain NotI and CpoI cohesive ends [22]. They ligated with $P$. pastoris expression vector pHBM905A [22], which was digested by NotI and CpoI restriction enzymes. The resultant plasmid was named pHBM905A-pel168. The plasmid pHBM905A-pel168s was constructed by similar method based on primers H1 and H2 (Table 2).

\section{Transformation and gene expression}

Plasmid pET28a-pel168 was transformed into E. coli BL21 (DE3), and the transformant was cultured in 50 $\mathrm{ml}$ LB medium with kanamycin $(50 \mu \mathrm{g} / \mathrm{ml})$. IPTG (isopropylthiogalactoside) at a final concentration of $0.5 \mathrm{mM}$ was added when $\mathrm{OD}_{600}$ reached 0.6. The culture was grown for $12 \mathrm{~h}$ at $18^{\circ} \mathrm{C}$ at $220 \mathrm{rpm}$. P. pastoris GS115 cells were prepared for transformation according to the manufacturer's instructions (Invitrogen). Recombinant plasmid $(10 \mu \mathrm{g})$ pHBM905A-pel168 and pHBM905Apel168s were linearized using SalI restriction enzyme so that the ampicillin resistance gene and the ColE1 origin of replication were removed from both [22]. The linearized fragments were separately transformed into yeast cells by electroporation. Plasmid pHBM 905A was used to prepare a control strain. The transformants were inoculated on BMMY plate containing pectin and the methanol was added on the plate lid every $12 \mathrm{~h}$. After $24 \mathrm{~h}$ culture and induction, transformants with the smallest halos that means single pel168 gene integration in the genome were cultured in $50 \mathrm{ml}$ BMGY liquid medium for $48 \mathrm{~h}$. Cells were

Table 2 Primers used in this study

\begin{tabular}{ll}
\hline Primers & Sequences \\
\hline P1 & 5'- CATTGGATCCATGAAAAAAGTGATGTTAGCTACGGC -3' \\
P2 & 5'-ATTCGCGGCCGCTTAATTTAATTAACCCGCACCCG -3' \\
G1 & 5'- GTCACAGCTGATTTAGGCCACCAGACGTGG -3' \\
G2 & 5'- GGCCATTAATTAATTACCCGCACCCG -3' \\
H1 & 5'- GTCACTCGAGGCCGACTTGGGACA -3' \\
H2 & 5'- GGCCAGAATTCTTAGTTAAGTTACCTGCTCCTGC-3' \\
\hline
\end{tabular}

harvested by centrifugation and suspended in $25 \mathrm{ml}$ BMMY liquid medium for gene expression. The cultures were incubated in BMMY for $96 \mathrm{~h}$ at $25^{\circ} \mathrm{C}$ at $220 \mathrm{rpm}$, and were supplemented with $1 \%$ methanol every $12 \mathrm{~h}$. The pectate lyase activity was assayed every $24 \mathrm{~h}$.

\section{Purification of recombinant pectate lyase}

E. coli transformant cells were harvested by centrifugation at $1500 \times g$ for $10 \mathrm{~min}$, and washed twice with PBS. The cells were suspended in PBS and disrupted by ultrasonication. The crude pectate lyase supernatant was purified by Ni-NTA column and Superdex 75 column. The pectate lyase from $P$. pastoris was concentrated by an Amicon Ultra-15 centrifugal filter device $(10 \mathrm{~K} \mathrm{MWCO}$ Millipore), and the protein sample was loaded on a Superdex 75 column. The molecular weight and purity of pectate lyase PEL168 were analyzed by SDS-PAGE (12\%).

\section{Deglycosylation of PEL168 from $P$. pastoris}

For enzymatic deglycosylation of $\mathrm{N}$-linked glycans, $18 \mu \mathrm{l}$ recombinant PEL168P was boiled for $10 \mathrm{~min}$ with $2 \mu \mathrm{l}$ denaturing buffer and then incubated at $37^{\circ} \mathrm{C}$ for $1 \mathrm{~h}$ with $1 \mu \mathrm{l}$ endoglycosidase $\mathrm{H}$, according to the manufacturer's instructions (New England Biolabs).

\section{Enzymatic characterization of pectate lyase}

Pectate lyase activity was assayed with $0.25 \%(\mathrm{w} / \mathrm{v})$ polygalacturonic acid (PGA; Sigma) as the substrate. Mixtures containing $20 \mu \mathrm{l}$ diluted enzyme solution and $480 \mu \mathrm{l}$ suspension of PGA in $0.05 \mathrm{M}$ buffer were incubated at different temperatures for $10 \mathrm{~min}$. The reducing sugar was determined by dinitrosalicylic acid procedure [23]. Galacturonic acid was used as a standard. One unit of enzyme activity was defined as the amount of enzyme capable of releasing $1 \mu \mathrm{mol}$ of reducing sugar from PGA per minute under the assay conditions. Pectate lyase activity was also assayed by measuring the increase in absorbance at $235 \mathrm{~nm}\left(\mathrm{~A}_{235}\right.$ method). One unit of enzyme activity was defined as the amount of enzyme capable of releasing $1 \mu \mathrm{mol}$ unsaturated oligogalacturonic acid of from PGA per minute under the assay conditions.

The optimum $\mathrm{pH}$ of the pectate lyase was determined at $50^{\circ} \mathrm{C}$ using four different $0.05 \mathrm{M}$ buffer systems: $\mathrm{Na}_{2} \mathrm{HPO}_{4}$-citric acid ( $\mathrm{pH}$ 4.0-6.0), sodium phosphate (pH 6.0-7.5), Tris- $\mathrm{HCl}(\mathrm{pH} 7.5-8.8)$ and glycine- $\mathrm{NaOH}$ (8.8-10.6). These experiments were performed in triplicate. The Statistical analyses of the experimental data were done with Microsoft Excel.

The kinetic parameters of PEL168P were determined at $50^{\circ} \mathrm{C}$ in $50 \mathrm{mM}$ sodium glycine- $\mathrm{NaOH}$ buffer $(\mathrm{pH} 9.4)$, and reactions were conducted for $3 \mathrm{~min}$ with $0.1 \mu \mathrm{M}$ PEL168P enzyme and PGA $(0.05-0.25 \mathrm{mg} / \mathrm{ml})$, in which the enzyme activity remained linear. The concentration of protein was measured by the method of Bradford 
with a protein assay kit from Bio-Rad, using bovine serum albumin as the standard.

To investigate the thermal stability of the enzyme, purified PEL168 was preincubated in the absence of substrates at 40,50 and $60^{\circ} \mathrm{C}$. Samples were taken at 5-min intervals during $30 \mathrm{~min}$, and the residual pectate lyase activities were measured at $50^{\circ} \mathrm{C}$ for $10 \mathrm{~min}$. The $\mathrm{pH}$ stability of PEL168P was also measured, and PEL168P was diluted in different buffers ranging from $\mathrm{pH} 4$ to 10.5 and stored at $4^{\circ} \mathrm{C}$ for $12 \mathrm{~h}$. The residual activities were measured at $50^{\circ} \mathrm{C}$ for $10 \mathrm{~min}$.

The effects of various metal ions and chemicals on PEL168P activity were measured by adding different metal ions at final concentrations of $5 \mathrm{mM}$ or chemicals at $0.5 \%(\mathrm{v} / \mathrm{v})$ into the reaction system. The degree of inhibition or activation of enzyme activity was expressed as a percentage of enzyme activity in the control sample (no additional metal ion and chemical agent presented).

\section{Degumming by PEL168 expressed in P. pastoris}

Degumming was performed according to Yang et al. [24]. The 5-g ramie fibers were boiled for $15 \mathrm{~min}$ in $250 \mathrm{ml}$ water and transferred to $200 \mathrm{ml}$ buffer of $0.05 \mathrm{M}$ Gly- $\mathrm{NaOH}$ (pH 9.4) including $1 \mathrm{ml}$ recombinant PEL168P, which is more than the requirement of the reaction. The mixture was incubated at $50^{\circ} \mathrm{C}$ for $1 \mathrm{~h}$. Controls had the same treatment without the addition of PEL168P.

\section{Additional file}

Additional file 1: (1) The sequence of pectate lyase gene pel168 before codon optimization. (2). The sequence of pectate lyase gene pel168 after codon optimization.

\section{Competing interests}

All of authors declare no competing interests.

\section{Authors' contributions}

$C J$ Zhang carried out the pectate lyase gene expression in P. pastoris and helped with the writing of the manuscript; I Yao carried out the pectate lysase gene expression in E.coli; C Zhou participated in the sequcence alignment and glycosylation analysis; LW Mao carried out the protein purification. GM Zhang designed the whole study and drafted the manuscript. YHM participated in its design and coordination and helped to draft the manuscript. All authors read and approved the final manuscript.

\section{Acknowledgements}

This study was supported by the Ministry of Science and Technology of China (863 program 2012AA022203C), the National Natural Science Foundation of China (31170068), the Natural Science Foundation of Hubei Province (2011CDA00302), the Science Project of Hubei Provincial Department of Education (D20101001), and the Knowledge Innovative Program of the Chinese Academy of Sciences (KSCX2-EW-G-8).

\section{Author details}

${ }^{1}$ College of Life Sciences, Hubei University, Wuhan 430062, China. ${ }^{2}$ State Key Laboratory of Microbial Resources, Institute of Microbiology, Chinese Academy of Sciences, Beijing 100101, China.

Received: 17 January 2013 Accepted: 12 March 2013 Published: 19 March 2013

\section{References}

1. Zheng L, Du Y, Zhang J: Degumming of ramie fibers by alkalophilic bacteria and their polysaccharide degrading enzymes. Bioresour Technol 2001, 78:89-94.

2. Basu S, Saha MN, Chattopadhyay D, Chakrabarti K: Degumming and characterization of ramie fibre using pectate lyase from immobilized Bacillus pumilus DKS1. Lett Appl Microbiol 2009, 48:593-597.

3. Kobayashi T, Hatada Y, Higaki N, Lusterio DD, Ozawa T, Koike K, Kawai S, Ito $\mathrm{S}$ : Enzymatic properties and deduced amino acid sequence of a high-alkaline pectate lyase from an alkaliphilic Bacillus isolated. Biochim Biophys Acta 1999, 1427:145-154.

4. Kobayashi T, Higaki N, Suzumatsu A, Sawada K, Hagihara H, Kawai S, Ito S: Purification and properties of a high molecular weight, alkaline exopolygalacturonase from a strain of Bacillus. Enzyme Microb Technol 2001, 29:377-383.

5. Li G, Rao L, Xue Y, Zhou C, Zhang Y, Ma Y: Cloning, expression, and characterization of a highly active alkaline pectate lyase from alkaliphilic Bacillus sp. N16-5. J Microbiol Biotechnol 2010, 20:670-677.

6. Liu W, Chao Y, Liu S, Bao H, Qian S: Molecular cloning and characterization of a laccase gene from the basidiomycete Fome lignosus and expression in Pichia pastoris. Appl Microbiol Biotechnol 2003, 63:174-181.

7. Zhang GM, Hu Y, Zhuang YH, Ma LX, Zhang XE: Molecular cloning and expression in Pichia pastoris of a xylanase gene from Bacillus pumilus HBP8. Biocatal Biotransform 2006, 24:371-379.

8. Daly R, Hearn MT: Expression of heterologous proteins in Pichia pastoris: a useful experimental tool in protein engineering and production. $J \mathrm{Mol}$ Recognit 2005, 18:119-138.

9. Pickersgill R, Jenkins J, Harris G, Nasser W, Robert-Baudouy J: The structure of Bacillus subtilis pectate lyase in complex with calcium. Nat Struct Biol 1994, 1:717-723.

10. Seyedarabi A, To TT, Ali S, Hussain S, Fries M, Madsen R, Clausen MH, Teixteira S, Brocklehurst K, Pickersgill RW: Structural insights into substrate specificity and the anti- $\beta$-elimination mechanism of pectate lyase. Biochemistry 2010, 49:539-546.

11. Nasser W, Awadé AC, Reverchon S, Robert BJ: Pectate lyase from Bacillus subtilis: molecular characterization of the gene, and properties of the cloned enzyme. FEBS Lett 1993, 335:319-326.

12. Guerrero-Olazarán M, Rodríguez-Blanco L, Carreon-Treviño JG, GallegosLópez JA, Viader-Salvadó JM: Expression of a Bacillus phytase C gene in Pichia pastoris and properties of the recombinant enzyme. Appl Environ Microbiol 2010, 76:5601-5608.

13. Yuan P, Meng K, Wang Y, Luo H, Shi P, Huang H, Tu T, Yang P, Yao B: A low-temperature-active alkaline pectate lyase from Xanthomonas campestris ACCC 10048 with high activity over a wide $\mathrm{pH}$ range. Appl Biochem Biotechnol 2012, 168:1489-1500.

14. Yuan P, Meng K, Shi P, Luo H, Huang H, Tu T, Yang P, Yao B: An alkalineactive and alkali-stable pectate lyase from Streptomyces sp. S27 with potential in textile industry. J Ind Microbiol Biotechnol 2012, 39:909-915.

15. Solbak Al, Richardson TH, McCann RT, Kline KA, Bartnek F, Tomlinson G, Tan X, Parra-Gessert L, Frey GJ, Podar M, Luginbühl P, Gray KA, Mathur EJ, Robertson DE, Burk MJ, Hazlewood GP, Short JM, Kerovuo J: Discovery of pectin-degrading enzymes and directed evolution of a novel pectate lyase for processing cotton fabric. J Biol Chem 2005, 280:9431-9438.

16. Akcapinar GB, Gul O, Sezerman U: Effect of codon optimization on the expression of Trichoderma reesei endoglucanase in Pichia pastoris. Biotechnol Prog 2011, 27:1257-1263.

17. Gao Z, Li Z, Zhang Y, Huang H, Li M, Zhou L, Tang Y, Yao B, Zhang W: High-level expression of the Penicillium notatum glucose oxidase gene in Pichia pastoris using codon optimization. Biotechnol Lett 2012, 34:507-514.

18. Catherine HS, Notebern HM: Mathieu Formation of soluble recombinant proteins in Escherichia coli is favored by lower growth temperature. Nat Biotechnol 1988, 6:291-294.

19. Basu S, Saha MN, Chattopadhyay D, Chakrabarti K: Large-scale degumming of ramie fibre using a newly isolated Bacillus pumilus DKS1 with high pectate lyase activity. J Ind Microbiol Biotechnol 2009, 36:239-245.

20. Brühlmann F, Leupin $M$, Erismann $K H$, Fiechter A: Enzymatic degumming of ramie bast fibers. J Biotechnol 2000, 76:43-50.

21. Brühlmann F, Kim KS, Zimmerman W, Fiechter A: Pectinolytic enzymes from actinomycetes for the degumming of ramie bast fibers. Appl Environ Microbiol 1994, 60:2107-2112. 
22. Zhang GM, Huang J, Huang GR, Ma LX, Zhang XE: Molecular cloning and heterologous expression of a new xylanase gene from plectosphaerella cucumerina. Appl Microbiol Biotechnol 2007, 74:339-346.

23. Miller GL, Blum R, Glennon WE, Burton AL: Measurement of carboxymethyl cellulase activity. Anal Biochem 1960, 2:127-132.

24. Yang XA, Peng YD, Tang SW, Yan L, Wen L, Zhu AG, Xiong HP: Optimization of Influencing Factors during Ramie Degumming with Mixed Enzymes. Hunan, China: Plant fibers and products; 2008:21-24.

doi:10.1186/1472-6750-13-26

Cite this article as: Zhang et al:: The alkaline pectate lyase PEL168 of Bacillus subtilis heterologously expressed in Pichia pastoris is more stable and efficient for degumming ramie fiber. BMC Biotechnology 2013 13:26.

\section{Submit your next manuscript to BioMed Central and take full advantage of:}

- Convenient online submission

- Thorough peer review

- No space constraints or color figure charges

- Immediate publication on acceptance

- Inclusion in PubMed, CAS, Scopus and Google Scholar

- Research which is freely available for redistribution 